Article

\title{
Deadwood Density and Moisture Variation in a Natural Temperate Spruce-Fir-Beech Forest
}

\author{
Tomáš Př́větivý ${ }^{1,2, *}$, Petr Baldrian ${ }^{3}$, Pavel Šamonil ${ }^{1}$ and Tomáš Vrška ${ }^{1}$ \\ 1 Department of Forest Ecology, Silva Tarouca Research Institute, Lidická 25/27, 60200 Brno, \\ Czech Republic; pavel.samonil@vukoz.cz (P.Š.); tomas.vrska@vukoz.cz (T.V.) \\ 2 Department of Silviculture, Faculty of Forestry and Wood Technology, Mendel University in Brno, \\ Zemědělská 3, 61300 Brno, Czech Republic \\ 3 Laboratory of Environmental Microbiology, Institute of Microbiology of the CAS, Vídeňská 1083, 14220 \\ Praha 4, Czech Republic; baldrian@biomed.cas.cz \\ * Correspondence: privetivy.tomas@gmail.com; Tel.: +420-541-126-232
}

\begin{abstract}
Deadwood represents a source of nutrients, carbon and water for metabolism within forest ecosystem. Nutrients are mobilized due to the decomposition of wood, which is a long-term process that can be best studied by analysing environmental data on a temporary scale. Our study provides physico-temporal data on the downed logs of three major tree species in European temperate forests: Abies alba Mill., Fagus sylvatica L. and Picea abies (L.) Karst. Time since death was obtained using tree censuses (repeated for 40 years) and dendrochronology for each single downed log, the oldest being 75 years old. Standard laboratory methods were used for the determination of wood density and moisture changes. F. sylvatica was decomposed rapidly in the initial phase - mass loss was $50 \%$ during the 5 years after death, while $A$. alba and $P$. abies lost $13 \%$ and $16 \%$, respectively. Downed logs of F. sylvatica contained $391 \mathrm{~kg}$ of water per $\mathrm{m}^{3}$, while these of $P$. abies $279 \mathrm{~kg}$. A logtransformed linear model was created that shows the dependence of time since death on mass loss. According to the model, F. sylvatica had the shortest total decomposition time (39 years), followed by $A$. alba (58 years) and P. abies (86 years).
\end{abstract}

Keywords: downed deadwood; decay stage; decomposition; wood density; wood moisture

\section{Introduction}

To study organisms living in decaying wood and the carbon cycling in forest ecosystems, it is important to understand the dynamics and decay rate of wood. During wood decomposition, the physical and chemical properties of wood change - wood density decreases, the $\mathrm{C} / \mathrm{N}$ ratio decreases as a result of $\mathrm{N}$ accumulation, while lignin content increases [1,2]. Decay rate can be used to forecast how much of a given amount of decaying wood survives in any subsequent period, which can help us to predict dynamics of some ecosystem components and changes in related biodiversity [3]. The decomposition of wood is closely associated with fungal activity. To quantify decomposition objectively, it is necessary to measure the physical properties of wood, including the remaining mass and density. Such changes in the physical and chemical properties of beech, fir and spruce deadwood correlate significantly with the fungal community structure [4].

In the temperate mixed forests of Continental Europe, the physical properties of deadwood and the dependence of mass loss on the time since death have been investigated for two important tree 
species - European beech (Fagus sylvatica L., hereafter "beech") and Norway spruce (Picea abies L. Karsten, hereafter "spruce"). These studies have been performed across different periods of time since death, and have reported the decomposition times of downed logs. For example, Kraigher et al. [5] covered the time since death of beech logs to 42 years, Müller-Using and Bartsch [6] measured downed beech logs through 28 years and Herrmann et al. [7] counted downed beech logs 8 and 18 years since death and spruce $\operatorname{logs} 8,18$ and 36 years since death. Many studies have been conducted in the boreal spruce forests of Northern Europe. For example, Næsset [3] obtained a maximum time since death of spruce logs of 32 years. Tarasov and Birdsey [8] covered the time since death of spruce logs to 71 years. In contrast, data about the dependence of mass loss on time since death or the decomposition times of downed logs for the deadwood of silver fir (Abies alba Mill., hereafter "fir"), an important tree species of temperate mixed forests in Continental Europe, have yet to be reported.

A number of studies have dealt with changes in deadwood moisture for major European tree species in particular decay stages [9-12], and it is generally assumed that deadwood moisture increases with time [1, 2]. However, explicit correlations between the time since death and moisture content have not yet been reported [13].To learn more about the basic physical properties of deadwood and their changes in time, we analysed samples from 150 downed logs in a natural temperate forest from a chronosequence dataset covering 61 years for beech, 63 years for spruce and 75 years for fir. We aimed to answer four questions for downed deadwood: (i) What are the differences between the decay stages of each species according to their mass and moisture, and how old is the downed deadwood that belongs to certain decay stages? (ii) What are the quantitative physical properties of deadwood (dry mass, water and carbon content) of beech, fir and spruce? (iii) How does the remaining mass and moisture change during decomposition? (iv) How long does it take for each species to completely decompose?

\section{Materials and Methods}

\subsection{Study site}

The Zofin Forest Dynamics Plot (25 ha, hereinafter "Zofin"), which is part of the ForestGEO network (www.forestgeo.si.edu), is situated in the central part of the Zofin national nature reserve in the Novohradské Hory Mts. (48 $\left.40^{\prime} \mathrm{N} 14^{\circ} 42^{\prime} \mathrm{E}\right)$, Czech Republic. The Zofin reserve has been under strict protection since 1838 (although deadwood was periodically removed until 1882) [14], and is a well-preserved remnant of a natural spruce-fir-beech forest in the Hercynian Mountains. An altitudinal gradient of 735-825 m a.s.l. is formed by gentle, predominantly NW slopes (for details see Janík et al. [16]). While terrestrial areas are predominated by Entic Podzols (classified according to [16]), hydromorphic sites are occupied particularly by Histic and Haplic Gleysols [17]. Annual average rainfall is $866 \mathrm{~mm}$, and annual average temperature is $6.2^{\circ} \mathrm{C}$. Plant communities can be most frequent classified in the association Galio odorati-Fagetum (terrestrial areas) or in the alliance Caricion remotae (spring areas), see details in Boublik et al. [18]. According to the 2012 tree census at the Zofin, beech predominates in the tree species composition (basal area (BA) 76\%, number of living trees (N) 95\%), followed by spruce (BA 19\%, N 4\%) and an admixture of fir (BA 5\%, N 1\%) [15].

\subsection{Field sampling}

This study used datasets from repeated tree censuses carried out in 1975, 1997, 2008 and 2012. All standing and downed trees of $\mathrm{DBH} \geq 10 \mathrm{~cm}$ at these sites had been mapped and the DBH recorded. 
Deadwood measurements (incl. lying stem lengths) were carried out according to the "Deadwood Protocol" [14]. Each lying stem was classified into one of three decay stages in each census when it was observed. The three decay stages were defined as follows: (i) Hard: the stem usually but not necessarily still has bark as well as relatively healthy and hard wood; (ii) Touchwood: the wood is not compact any more, with the core or outer mantle subjected to rot. Touchwood is a relatively widely defined class; in practice all downed logs that cannot be classified as 'hard' or 'disintegrated' fall into this category; (iii) Disintegrated: the wood is at a stage of advanced rot, a kick into a stem results in stem breakage, and often just little long mounds with patchy vegetation are present [14].

Stem volumes were calculated in PraleStat software (www.pralestat.wz.cz) based on volume tables and mathematic models of stem forms $[19,20]$. For more details on tree measurements and calculations, see Janík et al. [21] and Vrška et al. [22].

For sample selection the following criteria were chosen: (i) the decaying wood of the three main species (beech, fir and spruce) was evaluated; (ii) logs located close cored trees (relevant to dendrochronological evaluation of forest disturbance history, [23, 24]; (iii) only those downed logs that fell to the ground as living trees were chosen (i.e. excluding standing deadwood). This is important for subsequent analyses, since decaying for some time in a vertical position can significantly alter decay times [7,25]; (iv) we tried to choose numbers of downed logs for each period of time since death (derived from censuses) equally (Figure 1); (v) we tried to select mostly logs that were not suspended in the air. Fifty-three beech, 49 fir and 52 spruce downed logs that met the above criteria were sampled, with a resulting range of DBH of sampled logs from 40-100 cm.

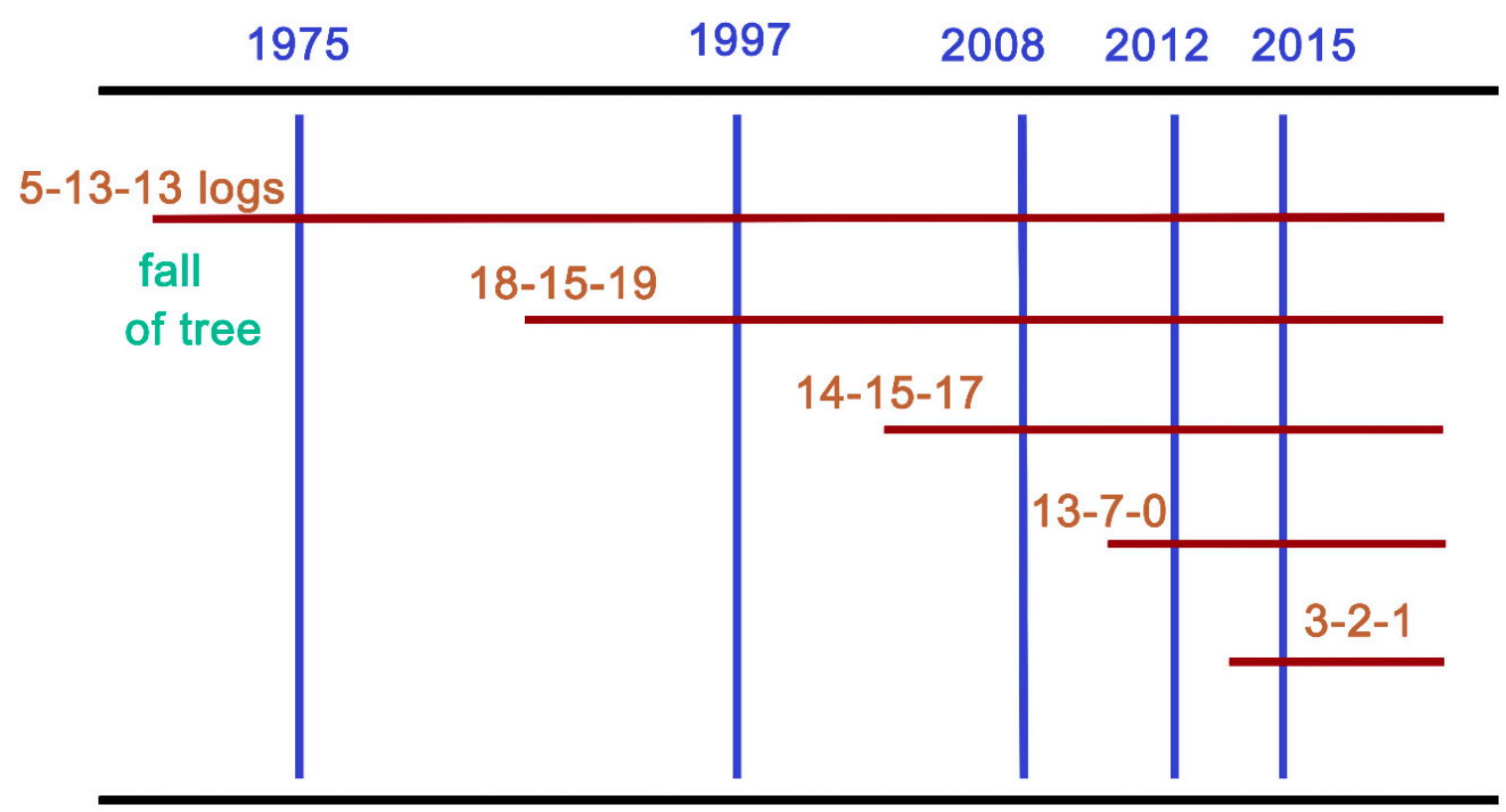

Figure 1. Scheme of the temporal distribution of downed logs (order of species: beech-spruce-fir) between censuses (1975-2015).

To determine time since death (hereafter "TSD") we used so called crossdating technique [26]. To date tree death we logically linked information from different data sets. Following 4 sources were used: (i) data available from repeated censuses (Figure 1); (ii) dendrochronological dating of living trees - where around 10 meters from the foot of the fallen $\log$ a live tree was cored and its response to disturbance due to death of adjacent tree was study in radial growth. Standard technique by 
Nowacki and Abrams [27] completed by boundary line approach by Black and Abrams [28] was used. Positive responses in radial growth $\geq 20 \%$ of boundary line were considered to be release [23, 24]; and the time since the year of release was assumed to be the TSD of the downed nearby log; (iii) Notes about downed logs that fell in winter 2007 were recorded in the 2008 census; (iv) The TSD of logs fallen before 1975 was derived from dendrochronologically dated logs fallen in this period with the help of their decay stage in the 1975 census (a TSD of 50 years for "hard", 60 years for "touchwood" and 75 years for "disintegrated")

\subsection{Laboratory analysis}

We chose one sample of decomposed wood per downed log from the base part or from the hardest part of the log. Samples were collected by an increment corer (inner diameter $12 \mathrm{~mm}$ ). Bore hole depth was measured by a vernier calliper, because the sample taken (pulp) could not be measured. The volume of the fresh sample was calculated as the volume of the cylinder. For some decayed logs from which it was not possible to collect a sample with the increment borer, a prism was removed with a saw and its volume was calculated by measuring the length, width and height. $\mathrm{DBH}$ was taken from the census database (original DBH measured in the first census after the fall of the tree).

Fragmentation of downed logs distorts data on wood density [7]. If fragmentation is not included, the mass loss in advanced TSD is very low. Therefore, if downed logs lost their original DBH by fragmentation, a fragmentation factor was calculated as the proportion of the current diameter to the initial diameter of the downed log. This factor was multiplied by the original (fresh) sample volume. However, we did not monitor fragmentation in the length of downed logs, and the fragmentation factor was not used for recalculating volumetric water contents. In addition, since samples of fir were collected in April 2016, while samples of beech and spruce were collected in June and August 2015, the moisture of fir was not compared with that of beech and spruce.

Samples were placed in sealable polypropylene bags and stored in a freezer to prevent the loss of water by evaporation. For analyses, each sample was first weighed to determine the fresh weight, using an analytical laboratory scale (accuracy $0.000 \mathrm{~g}$ ). The fresh wood density was calculated as the weight of the fresh sample divided by the fresh sample volume $\left(\mathrm{g} . \mathrm{cm}^{-3}\right)$. Then, drying was carried out at $105^{\circ} \mathrm{C}$ for 48 hours, after which samples were again weighed.

Samples for determining C concentration were taken from 39 beech, 36 fir and 43 spruce downed logs, and C was measured using sulfochromic oxidation (ISO 14235) [4].

\subsection{Terms used and data processing}

"Carbon concentration" is given as a percentage of the dry wood mass. "Dry mass" (density) is the weight of the dried sample divided by the fresh sample volume (g.cm $\left.{ }^{-3}\right)$. "Mass remaining" (\%) is the dry wood density divided by the dry density of a sample with TSD $=0$ (freshly fallen tree). To determine this dry density, samples were taken from 3 freshly fallen beech logs, 1 freshly fallen fir $\log$ and 2 freshly fallen spruce logs from the Zofin. Density values for these downed logs varied; therefore, values closest to the value from material tables [29] were taken. The densities used for beech wood with a TSD $=0$ was 0.711 g.cm ${ }^{-3}$, for fir 0.411 g.cm ${ }^{-3}$ and for spruce 0.402 g.cm ${ }^{-3}$. "Mass loss" is the dry mass lost during the decomposition process, and was calculated as 1 minus the mass remaining. 
Deadwood water concentration is expressed in two ways. Gravimetric (wet) water content (hereafter "wet mass moisture") is the weight of water in the wood sample divided by the mass of fresh wood sample. Volumetric water content (hereafter "volumetric moisture") is the volume of water in the wood sample divided by the volume of the fresh wood sample. The volume of water is calculated using the weight of water in the wood sample and the density of water. These concentrations are expressed as a percentage.

To perform multiple comparison tests for non-parametric data, a one-way ANOVA (KruskalWallis test) was conducted to further analyse possible differences in (1) moisture (wet mass moisture and volumetric moisture) between beech and spruce and to compare the moisture of different decay stages for each species, (2) carbon concentration between species and between decay stages for each species, (3) mass remaining at the species level and between species for each period of TSD (TSD of 0 years was not included in tests), and (4) wet mass moisture within species for each period of TSD. The level of significance was $\alpha=0.05$.

The degree of linear dependence between the two variables - dry mass (explanatory variable) and wet mass moisture (response variable) - was obtained with the help of Pearson's correlation coefficient (r).

Mean values for decay stages were calculated. To calculate the amount of downed deadwood dry mass, water quantity and carbon quantity per hectare, values on the volume of downed deadwood from the last census (2012) were taken into account.

"Total decomposition time" is the time during which $95 \%$ of a log's dry mass is decomposed (i.e. $95 \%$ mass loss and $5 \%$ of the mass still remaining). "Half-life" is the time during which $50 \%$ of a log's dry mass is decomposed (and 50\% of the mass still remains). A log-transformed linear model for each species was generated, where the explanatory variable was the mass loss of downed logs and the response variable was the TSD of the logs. Our main goal was to create a regression model from the TSD of individual logs for which wood density has been measured.

A decomposition constant ( $k$ ) was also calculated (according to Herrmann et al. [7]) and used to derive total decomposition times and half-lives (according to Mackensen and Bauhus [30]). Calculations, analysis, models and graphs were performed in the R package [31].

Mean values of dry mass and water content according to decay stages are easily reducible to units Mg. $\mathrm{m}^{-3}$ (tons per cubic meter). With these values, it is possible to estimate the amount of dry mass and water quantity of downed deadwood in any spruce-fir-beech forest stand.

\section{Results}

\subsection{Density, moisture and TSD charakteristics of decay stages}

The basic physical characteristics of decay stages are shown in Table 1. There was a significant difference between moisture in beech and spruce deadwood, with higher moisture in downed beech $\operatorname{logs}(\mathrm{p}=0.002$ for wet mass moisture, $\mathrm{p}=0.003$ for volumetric moisture). 
Table 1. Mean values of physical properties for decay stages of downed logs. Values for beech and spruce logs were estimated in the summer, values for fir logs are were estimated in the spring. Different letters indicate significant differences among the decay stages within species $(\alpha=0.05)$.

\begin{tabular}{|c|c|c|c|c|c|c|c|c|c|c|c|}
\hline \multirow[b]{2}{*}{ Species - decay stage } & \multirow[b]{2}{*}{$\mathrm{N}$} & \multicolumn{2}{|c|}{$\begin{array}{l}\text { Dry mass } \\
\left(\mathrm{g} \cdot \mathrm{cm}^{-3}\right)\end{array}$} & \multicolumn{2}{|c|}{$\begin{array}{c}\text { Mass } \\
\text { remaining }\end{array}$} & \multicolumn{2}{|c|}{ Wet mass moisture (\%) } & \multicolumn{2}{|c|}{$\begin{array}{l}\text { Volumetric } \\
\text { moisture (\%) }\end{array}$} & \multicolumn{2}{|c|}{ TSD } \\
\hline & & Mean & SD & Mean & SD & Mean & SD & Mean & SD & Mean & SD \\
\hline Beech - Hard & 22 & 0.392 & 0.136 & $55.0 \%$ & 19.1 & $47.8(\mathrm{a})$ & 13.1 & 37.4 (a) & 18.7 & 7 & 3 \\
\hline Beech - Touchwood & 18 & 0.236 & 0.084 & $33.2 \%$ & 11.8 & $57.0(\mathrm{~b})$ & 14.9 & 33.5 (a) & 15.7 & 22 & 11 \\
\hline Beech - Disintegrated & 11 & 0.149 & 0.096 & $20.9 \%$ & 13.4 & $69.6(\mathrm{c}$ & 9.8 & $51.7(b)$ & 22.1 & 38 & 12 \\
\hline Spruce - Hard & 19 & 0.339 & 0.051 & $84.4 \%$ & 12.6 & $36.8(a)$ & 11.7 & $22.0(a)$ & 12.9 & 7 & 3 \\
\hline Spruce - Touchwood & 22 & 0.272 & 0.075 & $67.8 \%$ & 18.7 & 47.9 (b) & 12.8 & $27.6(a b)$ & 15.7 & 36 & 18 \\
\hline Spruce - Disintegrated & 10 & 0.172 & 0.097 & $42.7 \%$ & 24.1 & $62.0(\mathrm{~b})$ & 21.8 & $40.0(\mathrm{~b})$ & 34.0 & 42 & 14 \\
\hline Fir - Hard & 12 & 0.309 & 0.083 & $75.1 \%$ & 20.3 & $51.5(\mathrm{a})$ & 11.0 & $34.3(\mathrm{a})$ & 15.5 & 8 & 3 \\
\hline Fir - Touchwood & 23 & 0.252 & 0.063 & $61.3 \%$ & 15.4 & $55.3(\mathrm{a})$ & 12.7 & 35.0 (a) & 16.7 & 31 & 16 \\
\hline Fir - Disintegrated & 14 & 0.126 & 0.065 & $30.7 \%$ & 15.9 & $71.8(\mathrm{~b})$ & 9.2 & 48.9 (b) & 18.4 & 49 & 20 \\
\hline
\end{tabular}

The wet mass moisture of downed wood increased with increasing decay stage. There were also significant differences between decay stages among species. Each decay stage was different for beech, while some decay stages for fir and spruce were similar in terms of wet mass moisture (Table 1). The volumetric moisture of CWD also increased with increasing decay stage; however, there was no significant difference between "hard" and "touchwood" (Table 1).

Mean TSD showed the average residence time of downed logs in different decay stages (Table 1, Figure 2). The decay stage "hard" had a narrow range of TSD, while the decay stages "touchwood" and "disintegrated" contained downed logs with a wide range of TSD with considerable overlap (Figure 2).

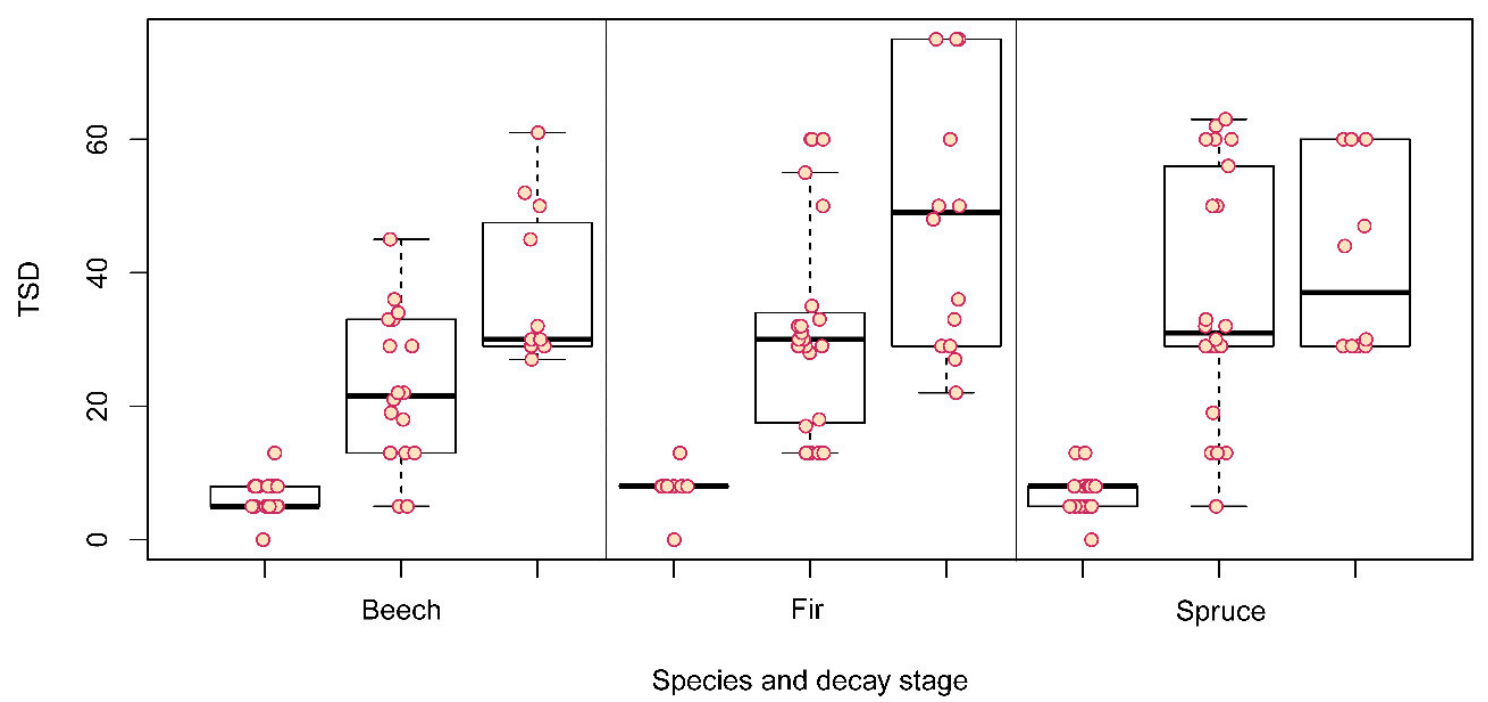

Figure 2: Range of TSD in decay stages for the three species. 1 - decay stage "hard", 2 - decay stage "touchwood", 3 - decay stage "disintegrated". 


\subsection{Dry mass, carbon and water quantity of downed logs}

During the 2012 census at the Zofin, the following total amounts of dry mass in downed deadwood were recorded: $23.7 \mathrm{Mg}$.ha-1 in beech logs, $15.5 \mathrm{Mg}^{-h^{-1}}{ }^{-1}$ in fir logs and $46.0 \mathrm{Mg}$.ha-1 in spruce logs; in total $85.1 \mathrm{Mg}^{-h^{-1}}{ }^{-1}$ The volume of deadwood represented a significant of the aboveground wood volume, downed deadwood comprised $33.0 \%$ of the aboveground wood volume, and standing deadwood comprised $10.6 \%$ of the aboveground volume.

Carbon concentrations varied among the tree species sampled. The mean $\mathrm{C}$ concentration value for downed beech logs was $44.2 \%$ (SD 3.6), for fir 46.5\% (SD 4.0) and for spruce $48.2 \%$ (SD 4.1). The carbon concentration of beech logs was significantly different from logs of fir and spruce, while concentrations in fir and spruce logs did not differ significantly. Differences between decay stages were also not significant. In transition from the decay stage "hard" to "touchwood", the mean value of C concentration increased by 2.4-5.6\%, while from the decay stage "touchwood" to "disintegrated" the mean $C$ concentration decreased by $0.6-2.1 \%$. The carbon concentration was relatively constant along the decay stages. The following carbon quantities were recorded in downed

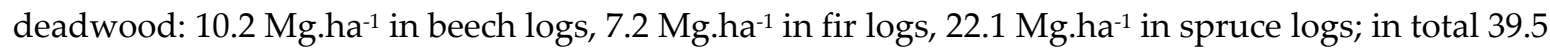
Mg.ha-1.

The water quantity was $29.5 \mathrm{Mg} \cdot \mathrm{ha}^{-1}$ in downed beech logs and $37.5 \mathrm{Mg}^{-} \mathrm{ha}^{-1}$ in downed spruce logs in the summer, and was $25.6 \mathrm{Mg} \cdot \mathrm{ha}^{-1}$ in downed fir logs in the spring.

\subsection{Changes in density and moisture during th decomposition process}

The course of the remaining mass since TSD is shown in Figure 3. The remaining mass of decaying wood decreased with increasing TSD, though differently for different tree species. A sharp decline of remaining mass was observed for downed beech logs - of $50 \%$ within 5 years after death, while the remaining mass was $85 \%$ for downed spruce logs 5 years after death. 12 years after death, the remaining mass dropped to an average of $45 \%$ for beech logs and $84 \%$ for spruce logs. However, this change of remaining mass between 5 and 12 years after death was not significant for either beech or spruce. The remaining mass of downed fir logs decreased to $69 \% 12$ years after death. 29 years after death, remaining masses decreased to $32 \%$ for beech logs, $52 \%$ for fir logs and $61 \%$ for spruce logs, and these differences between TSDs of 12 and 29 years were significant for all three species. During the last period of TSD (60 years), the remaining mass decreased on average to $20 \%$ for beech $\operatorname{logs}, 47 \%$ for fir logs and 51\% for spruce logs (Figure 3). However, these differences between 29 and 60 years after death were not significant for all three species. 


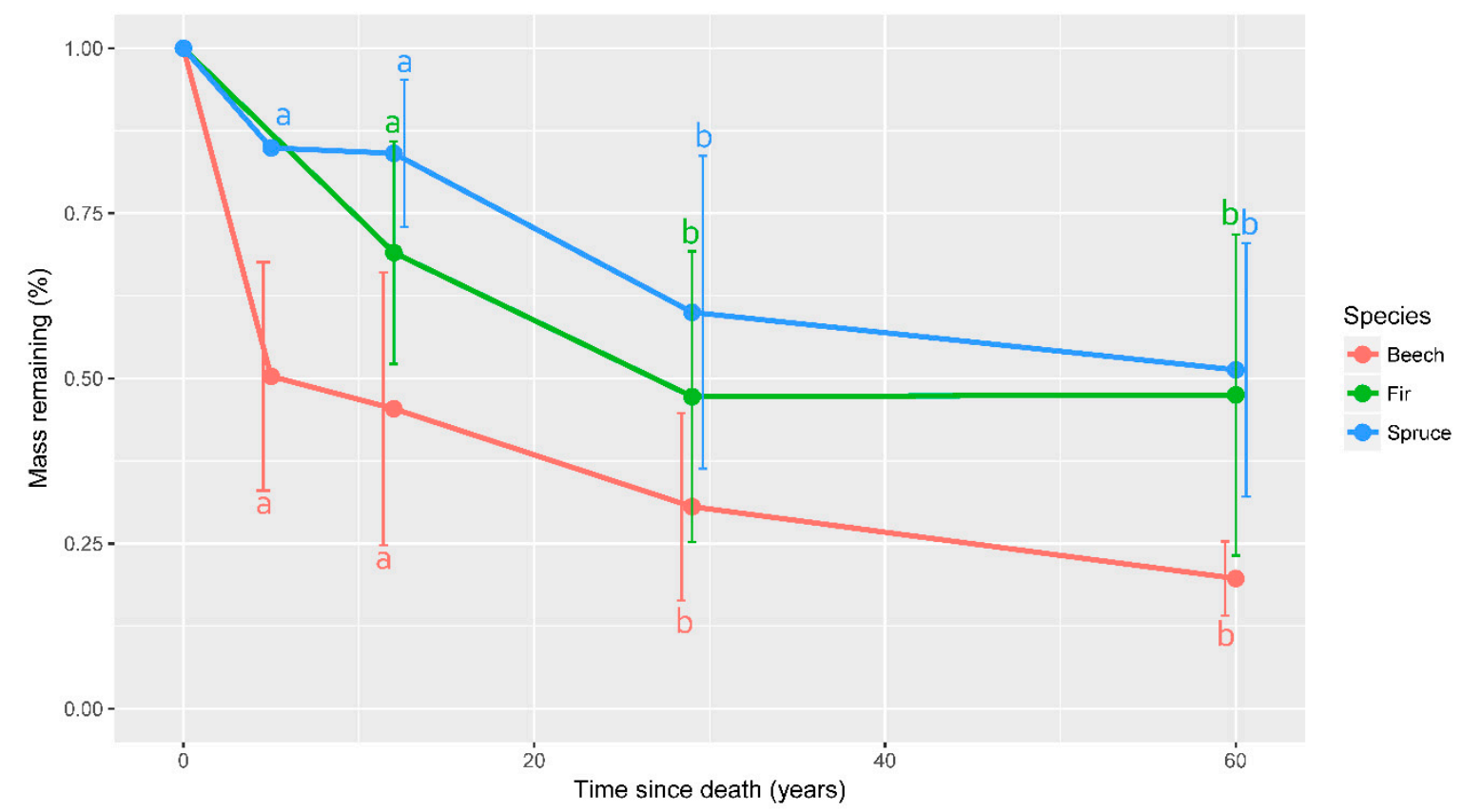

Figure 3. Changes in the remaining mass over time (means and SD; TSD determined from censuses).

Different letters indicate significant differences among the logs from a particular census $(\alpha=0.05)$.

The remaining masses at the same TSD between the tree species were also compared. 12 years after death, fir had significantly lower remaining mass than spruce, demonstrating that by this time fir had decomposed faster than spruce. However, the remaining masses of fir and spruce were not significantly different after 29 and 60 years since death. Beech had significantly lower remaining mass than fir and spruce at each period of TSD. In contrast, values of dry mass between species at each TSD were not significantly different. Starting with 5 years after death, the values of dry mass in the decomposition process were similar for all three species.

We also found different processes for downed beech and spruce deadwood in the changes of wet mass moisture since TSD (Figure 4). In beech deadwood, there was a continuous increase but with some stagnation (12 years after death). However, downed logs with TSD 5, 12 and 29 years were not significantly different in their wet mass moisture (Figure 4). Moisture in spruce deadwood increased until around the half-time of the decomposition process (29 years after death) and then was steady. The changes in wet mass moisture since TSD for downed fir deadwood was similar to spruce, but the value for fir was markedly higher, most likely due to sampling in different seasons. Fir downed logs with TSD of 12 years had significantly lower wet mass moisture than logs with 29 and 60 years (Figure 4 ). 


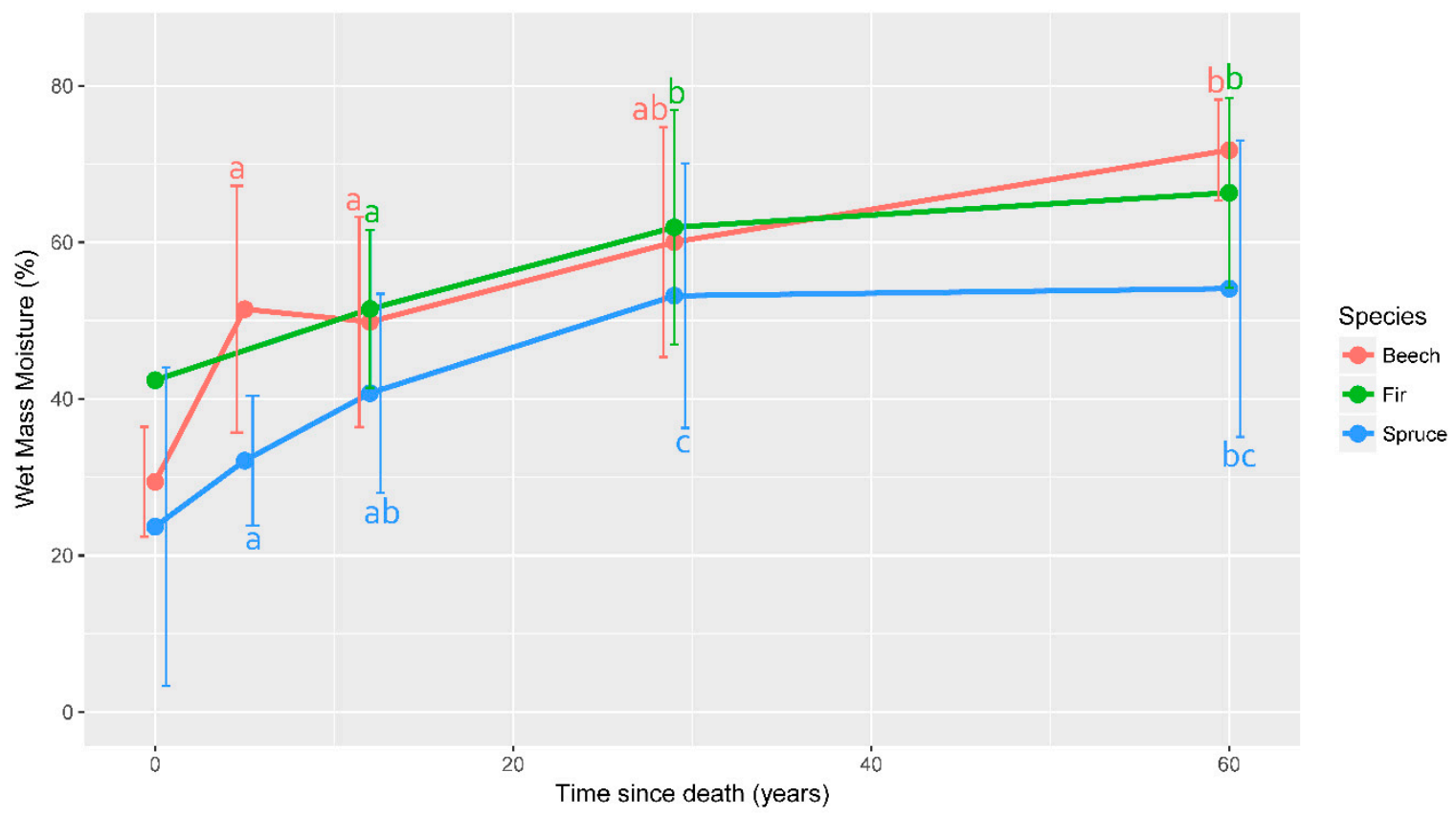

Figure 4. Changes in wet mass moisture over time (means and SD; TSD determined from censuses).

Different letters indicate significant differences among the logs from a particular census $(\alpha=0.05)$.

The degree of linear dependence between the dry mass and wet mass moisture (Pearson's correlation coefficient $r$ ) is shown in Figure 5. The models of these variables show decreasing linear relationships, with the following $R$-squared and $p$-values: for beech $R^{2}=0.41, p=1.56^{e}$, for fir $R^{2}=0.29$, $\mathrm{p}=3.85^{\mathrm{e} 5}$ and for spruce $\mathrm{R}^{2}=0.26, \mathrm{p}=6.93^{\mathrm{e}}$.
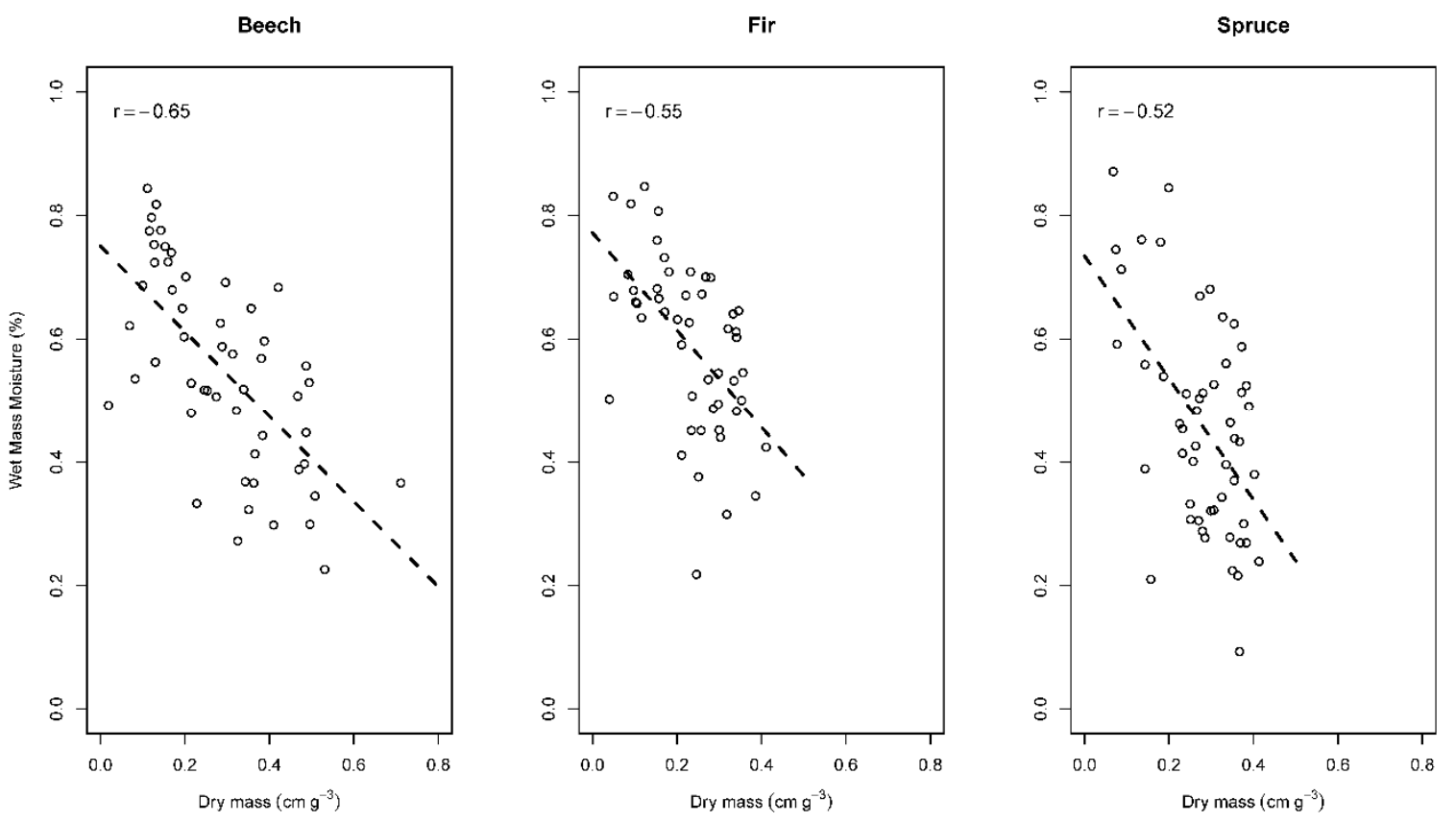

Figure 5. Linear regression model between the dry mass and wet mass moisture. 


\subsection{Decomposition time of downed logs}

Values of the half-life and total decomposition time deducted from the log-transformed linear model are shown in Figure 6. The half-life for downed beech logs was 10 years and the total decomposition time was 39 years $\left(\mathrm{R}^{2}=0.51, \mathrm{p}=1.62^{\mathrm{e}}\right)$. The estimated half-life for downed fir logs was 25 years and the total decomposition time was 58 years $\left(R^{2}=0.23\right.$, $\left.\mathrm{p}=2.70^{\mathrm{e}}\right)$. The estimated half-life for downed spruce logs was 30 years and the total
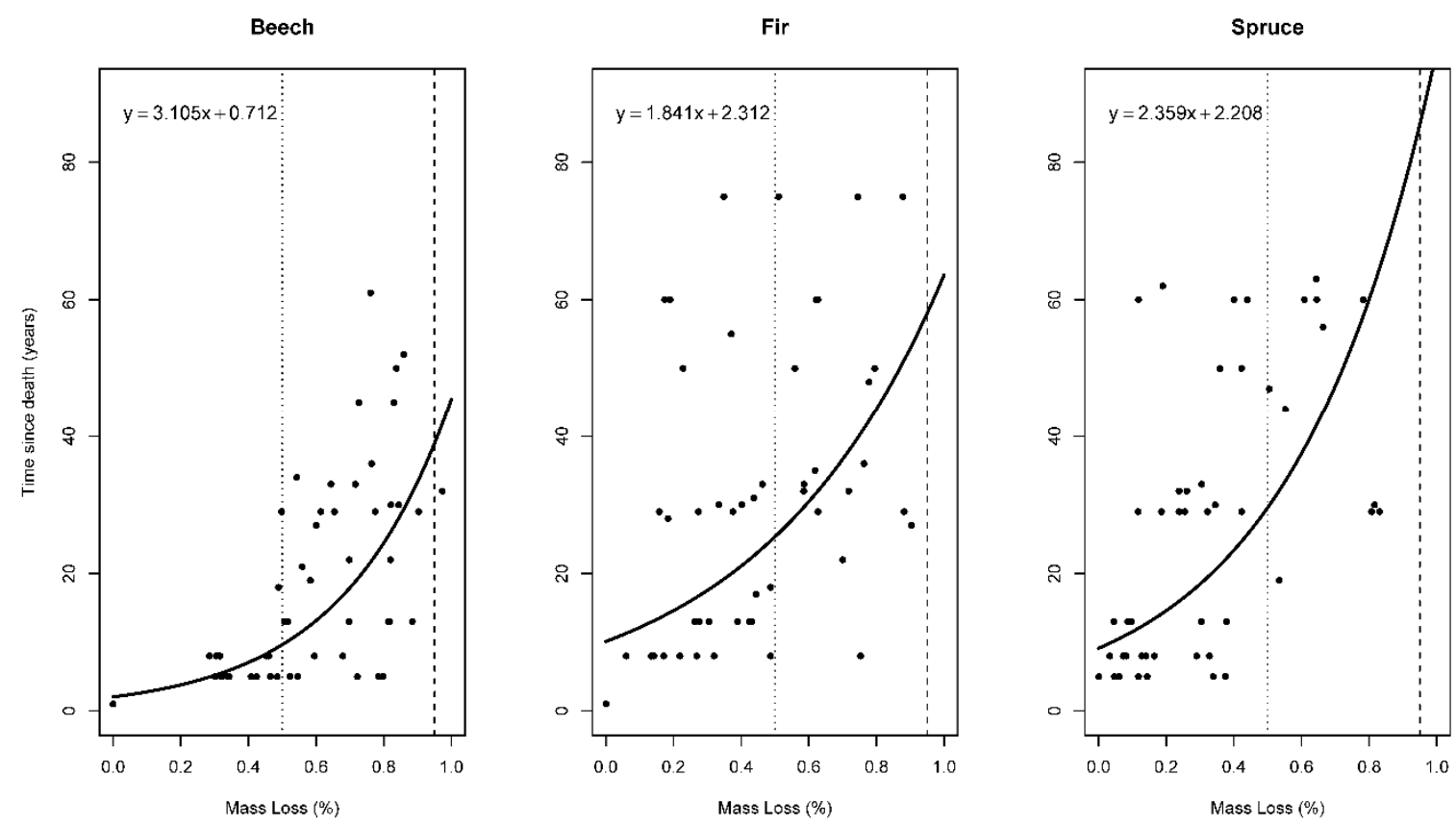

decomposition time was 86 years $\left(\mathrm{R}^{2}=0.35, \mathrm{p}=3.09 \mathrm{e} 6\right)$. Figure 6. Log-transformed linear model of the total decomposition time and half-life of downed logs. TSD is an observed value.

The mean decomposition constants were 0.085 for beech, 0.030 for fir, and 0.021 for spruce. Thus, the derived total decomposition times were 140 years for spruce, 99 years for fir and 35 years for beech.

\section{Discussion}

\subsection{Density, moisture and TSD charakteristics of decay stages}

Downed logs that stayed the same amount of time at the same site showed highly divergent values of dry mass content. Decay stages "touchwood" and "disintegrated" had a wide range of TSD, and their marginal TSDs largely overlapped (Figure 2). In other words, the downed logs achieved the same decay stage after varying TSD. The rate of downed deadwood decomposition was strongly different among logs. This was due to the qualitative properties of the downed logs: diameter (sampled logs with DBH 40-100 cm) and position - logs in contact with the ground and suspended $\operatorname{logs}(16 \%$ of sampled logs). Beech logs in contact with the soil have been shown to have a shorter duration of the decay stages "hard" and "touchwood" (ca. 9-15 years less) than suspended logs [25]. Micro environmental conditions (temperature, water availability and gaseous regime) played a role, and likely influenced the composition of saproxylic fungi communities and respirational carbon loss [32]. Herrmann et al. [7] also observed high variation in deadwood density within decay classes and 
hence only few significant differences between adjacent decay classes within a given species. This study did not aim to test the various factors influencing the different decay times of individual downed logs, but our intention was rather to describe decomposition using the most homogeneous set of sampled logs available.

An important process that affects decomposition is fragmentation, which was found to be of increasingly important in later decomposition stages [33, 6]. Fragmentation in terms of the length or thickness of downed logs significantly affects the value of mass loss. Herrmann et al. [7] observed a maximum annual fragmentation of $1.02 \%$ of the total mass for downed spruce logs after 18 years, but the studied logs were mainly at the beginning and the middle of the decomposition process.

\subsection{Changes in density and moisture during the decomposition process}

During decomposition, deadwood moisture increased while density decreased. Mackensen and Bauhus [30] observed the same trend of moisture within TSD classes, with moisture content increasing with age through 1-12 years of TSD for one species of Pinus and two species of Eucalyptus [30]. We can compare these observations with the changes in moisture and density through the decay stages. Petrillo et al. [12] stated that an increasing water content and decreasing density of deadwood during the decomposition process could be explained by the gradual loss of wood structure (relationship in Figure 5). In contrast, Pichler et al. [13] found that the moisture of beech deadwood reached maximum values in decay stage 2 and moisture decreased in decay stage 3, while the moisture of spruce deadwood reached minimum values in decay stage 2 (showing a U-shaped distribution). Bütler et al. [9] also described minimum values of spruce deadwood moisture in decay stage 2, which then increased in advanced decay stages. In another study, Paletto and Tossi [10] also found a typical U-shaped distribution for deadwood moisture during decay. Pichler et al. [13] also studied annual trends of deadwood moisture.

Comparing the density value of decaying wood from various studies, we can observe major differences within the various decomposition stages and various times since death. This is caused mainly by methodological differences [11] or different environmental conditions [10].

\subsection{Decomposition times of downed logs}

Based on deadwood density data, downed beech logs had the shortest estimates of total decomposition time (39 years), followed by fir (58 years), while downed spruce logs had the longest predicted total decomposition time (86 years). The rather short total decomposition time of downed beech logs was caused by the fact that many logs reached a mass loss of $0.6-0.8$ after just $5-12$ years (Figure 6). The average remaining mass after 5 years of TSD was 50\% (Figure 3). The adjusted Rsquared value for log-transformed linear regression for downed beech logs was 0.51 , for downed fir logs was 0.23 and for spruce was 0.35 . The model thus described only one quarter to one half of the variability, and although statistically significant was not quite strong.

Although the beech logs sampled around 60 years after death had a remaining mass of $20 \%$ (Figure 3), the estimated total decomposition time was 39 years. Similarly for fir, logs had $47 \%$ remaining mass around 60 years after death, while the estimated total decomposition time was 58 years. Thus, these were logs that resided exceptionally long, since, already decomposed logs were not a part of this dataset. With increasing time since death the numbers of completely decayed logs increases as explained by the residence trajectory [25]. For this reason, it is not possible to precisely deduce the decomposition time from the changes of remaining mass over time. 
Our calculated decomposition constant $(k)$ for spruce (0.021) and the derived decomposition time (140 years) appear to be excessive. For example, Herrmann et al. [7] reported a decomposition constant for spruce of 0.033 , and Næsset [34] also found a mean $k$ value of 0.033 . In addition, our calculated decomposition time for fir (99 years) seems excessively high. The reason these decomposition constants and decomposition times are inadequate is likely because the least decomposed parts of logs were sampled, and in older logs only those logs that were suitable for measurement (not yet fully decomposed) were sampled. To obtain a decomposition time that would correspond to the average decomposition time of the entire dataset of all logs, it would be necessary to sample already-decayed logs, which is technically unfeasible. Our calculated decomposition constant for beech (0.085) seems more realistic; for example Müller-Using and Bartsch [6] computed a $k$ value of 0.089 , and Herrmann et al. [7] reported 0.054. Finally, in a study examining the trajectory of downed beech deadwood from natural temperate forests in Central Europe [25], total decomposition times in the same site for diameter classes $10-24 \mathrm{~cm}, 25-54 \mathrm{~cm}$ and $55+\mathrm{cm}$ were 30, 41 and 43 years, respectively. These are in line with the total decomposition times estimated in this study.

\section{Conclusions}

This paper aimed to determine (i) the mass and moisture of the decay stages of beech, fir and spruce, and the range of TSD for decay stages, (ii) the quantitative physical properties of deadwood (dry mass, water, and carbon), (iii) changes in the remaining mass and moisture during decomposition and (iv) estimates of deadwood decomposition time.

(Ad i) downed logs achieved the same level of mass loss (and decay stage) after varying TSD. The variance in the remaining mass of downed logs with the same TSD was especially high for fir and spruce. (Ad ii) decaying beech wood contains a significantly higher amount of water than spruce wood in absolute terms. Downed beech logs contained $391 \mathrm{~kg}$ of water per $\mathrm{m}^{3}$ on average, while downed spruce logs contained $279 \mathrm{~kg} \cdot \mathrm{m}^{-3}$. Samples from downed fir logs contained $388 \mathrm{~kg}$ of water per $\mathrm{m}^{3}$ in the spring season. (Ad iii) while sound beech wood had a higher density $\left(0.52-0.71 \mathrm{~g} . \mathrm{cm}^{-3}\right.$ in our samples) than spruce and fir wood $\left(0.37-0.41 \mathrm{~g} . \mathrm{cm}^{-3}\right)$, it was subject to faster degradation in the initial phase of decomposition. Downed beech deadwood had a similar dry mass as coniferous species after 5 years of decay. Differences in values of remaining mass between periods of time since death 12 and 29 years were significant for all three species. (Ad iv) the estimated total decomposition time for downed beech deadwood was 39 years, for fir 58 years and for spruce 86 years. The amount of deadwood dry mass (with average carbon content $46 \%$ ) and water in downed logs play a significant role in the ecological processes of natural forests in the temperate zone.

Acknowledgments: We would like to thank the Department of Wood Science in Mendel University in Brno for facilitating the laboratory analysis, to Iveta Šedová for help during sampling. Péter Szabó and David Hardekopf carried out the proofreading. Petra Doleželová and Dušan Adam helped us with technical issues. This work was supported by the Internal Grant Agency of Mendel University in Brno; under Grant number 6/2015 “Deadwood density variation with time since death of Picea abies and Fagus sylvatica"; and by the Czech Science Foundation under Grant number 13-27454S.

Author Contributions: T.P. and T.V. conceived and designed the experiments; P.Š. designed dendrochronological dating of mortality events; T.P. collected the data; P.B. measured carbon concentrations; T.P. analyzed the data; T.P. wrote the paper; P.B., P.S. and T.V. edited the paper. 
Conflicts of Interest: "The authors declare no conflict of interest." "The founding sponsors had no role in the design of the study; in the collection, analyses, or interpretation of data; in the writing of the manuscript, and in the decision to publish the results".

\section{References}

1. Kubartová, A.; Ottosson, E.; Dahlberg, A.; Stenlid, J. Patterns of fungal communities among and within decaying logs; revealed by 454 sequencing. Mol Ecol 2012, 21, 4514-4532, doi: 10.1111/j.1365294X.2012.05723.x.

2. Hoppe, B.; Purahong, W.; Wubet, T.; Kahl, T.; Bauhus, J.; Arnstadt, T.; Hofrichter, M.; Buscot, F.; Krüger D. Linking molecular deadwood-inhabiting fungal diversity and community dynamics to ecosystem functions and processes in Central European forests. Fungal Divers 2015, 77, 367-379, doi: 10.1007/s13225015-0341-x.

3. Næsset, E. Relationship Between Relative Wood Density of Picea abies Logs and Simple Classification Systems of Decayed Coarse Woody Debris. Scand J For Res 1999b, 14, 454-461, doi: 10.1080/02827589950154159.

4. Baldrian, P.; Zrůstová, P.; Tláskal, V.; Davidová, A.; Merhautová, V.; Vrška, T. Fungi associated with decomposing deadwood in a natural beech-dominated forest. Fungal Ecol. 2016, 23, 109-122, doi: 10.1016/j.funeco.2016.07.001.

5. Kraigher, H.; Jurc, D.; Kalan, P.; Kutnar, L.; Levanic, T.; Rupel, M.; Smolej, I. Beech Coarse Woody Debris Characteristics in two Virgin Forest Reserves in Southern Slovenia. Deliverable 9 \& 15 of the Nat-Man Project Produced under Work-Package 7, 2003.

6. Müller-Using, S.; Bartsch, N. Decay dynamic of coarse and fine woody debris of beech (Fagus sylvatica L.) forest in Central Germany. Eur J Forest Res 2009, 128, 287-296, doi: 10.1007/s10342-009-0264-8.

7. Herrmann, S.; Kahl, T.; Bauhus J. Decomposition dynamics of coarse woody debris of three important central European tree species. For Ecosyst 2015, 2, 27, doi: 10.1186/s40663-015-0052-5.

8. Tarasov, M.E.; Birdsey, R.A. Decay rate and potential storage of coarse woody debris in the Leningrad Region. Ecol Bull 2001, 49, 137-147.

9. Bütler, R.; Patty, L.; Le Bayon, R-C.; Guenat, C.; Schlaepfer, R. Log decay of Picea abies in the Swiss Jura Mountains of central Europe. For Ecol Manage 2007, 242, 791-799, doi:10.1016/j.foreco.2007.02.017

10. Paletto, A.; Tossi, V. Deadwood density variation with decay class in seven tree species of the Italian Alps. Scand J For Res 2010, 25, 164-173, doi: 10.1080/02827581003730773.

11. Teodosiu, M.; Bouriaud, O.B. Deadwood specific density and its influential factors: A case study from a pure Norway spruce old-growth forest in the Eastern Carpathians. For Ecol Manage 2012, 283, 77-85, doi: 10.1016/j.foreco.2012.06.050.

12. Petrillo, M.; Cherubini, P.; Sartori, G.; Abiven, S.; Ascher, J.; Bertoldi, D.; Camin, F.; Barbero, A.; Larcher, R.; Egli, M. Decomposition of Norway spruce and European larch coarse woody debris (CWD) in relation to different elevation and exposure in an Alpine setting. iForest 2015, 9, 154-164, doi: 10.3832/ifor1591-008.

13. Pichler, V.; Homolák, M.; Skierucha, W.; Pichlerová, M.; Ramírez, D.; Gregor, J.; Jaloviar, P. Variability of moisture in coarse woody debris from several ecologically important tree species of the Temperate Zone of Europe. Ecohydrol 2011, 5, 424-434, doi: 10.1002/eco.235.

14. Král, K.; Valtera, M.; Janík, D.; Šamonil, P.; Vrška T. Spatial variability of general stand characteristics in central European beech-dominated natural stands - Effects of scale. For Ecol Manage 2014, 328, 353-364, doi: 10.1016/j.foreco.2014.05.046.

15. Janík, D.; Král, K.; Adam, D.; Hort, L.; Šamonil. P.; Unar. P.; Vrška, T.; McMahon, S. Tree spatial patterns of Fagus sylvatica expansion over 37 years. For Ecol Manage 2016, 375, 134-145, doi: 10.1016/j.foreco.2016.05.017.

16. Michéli, E.; Schad, P.; Spaargaren, O.; Dent, D.; Nachtergale, F. World reference base for soil resources 2006. World Soil Resources Reports; vol. 103. Food and Agricultural Organization of the United Nations. Rome, Italy, 2006.

17. Šamonil, P.; Valtera, M.; Bek, S.; Šebková, B.; Vrška, T.; Houška, J. Soil variability through spatial scales in a permanently disturbed natural spruce-fir-beech forest. Eur J For Res 2011, 130, 1075-1091, doi: 10.1007/s10342-011-0496-2.

18. Boublik, K.; Lepši, M.; Lepši, P. Vegetation of the Žofinský Prales nature reserve (Novohradske Hory Mts., Czech Republic). Silva Gabreta 2009, 15, 121-142. 
19. Anonymous. Hmotové tabulky [Mass tables]. Lesprojekt 1952, Brandýs nad Labem.

20. Petráš, R. Matematický model tvaru kmeňa listnatých drevín. Lesnícky časopis 1990, 36, 231-241

21. Janík, D.; Adam, D.; Vrška, T.; Hort, L.; Unar, P.; Horal, D.; Král, K.; Šamonil, P. Tree layer dynamics of the Cahnov-Soutok near natural floodplain forest after 33 years (1973-2006). Eur J For Res 2008, 127, 337-345, doi: 10.1007/s10342-008-0210-1.

22. Vrška, T.; Šamonil, P.; Unar, P.; Hort, L.; Adam ,D.; Král, K.; Janík D. Developmental dynamics of virgin forest reserves in the Czech Republic III - Šumava Mts and Český les Mts (Diana; Stožec; Boubín virgin forest; Milešice virgin forest). Academia: Praha, Czech Republic, 2012; ISBN 978-80-200-1907-3.

23. Šamonil, P.; Schaetzl, R.J.; Valtera, M.; Goliáš, V.; Baldrian, P.; Vašíčková, I.; Adam, D.; Janík, D.; Hort, L. Crossdating of disturbances by tree uprooting: Can treethrow microtopography persist for 6000 years? For Ecol Manage 2013a, 307, 123-135, 10.1016/j.foreco.2013.06.045.

24. Vašíčková, I.; Šamonil, P.; Fuentes, U.A.E.; Král, K.; Daněk, P.; Adam, D. The true response of Fagus sylvatica L. to disturbances: A basis for the empirical inference of release criteria for temperate forests. For Ecol Manage 2016, 374, 174-185, doi: 10.1016/j.foreco.2016.04.055.

25. Přívětivý, T.; Janík, D.; Unar, P.; Adam, D.; Král, K.; Vrška, T. How do environmental conditions affect the deadwood decomposition of European beech (Fagus sylvatica L.)? For Ecol Manage 2016, 381, 177-187, doi: 10.1016/j.foreco.2016.09.033.

26. Šamonil, P.; Doleželová, P.; Vašíčková, I.; Adam, D.; Valtera, M.; Král, K.; Janík, D.; Šebková, B. Individualbased approach to the detection of disturbance history through spatial scales in a natural beech-dominated forest. J Veg Sci 2013b, 24, 1167-1184, 10.1111/jvs.12025.

27. Nowacki, G.J.; Abrams, M.D. Radial-growth averaging criteria for reconstructing disturbance histories from presettlement-origin oaks. Ecol Monogr 1997, 67, 225-249, doi: 10.2307/2963514.

28. Black, B.A.; Abrams, M.D. Use boundary-line growth patterns as a basis for dendroecological release criteria. Ecol Appl 2003, 13, 1733-1749, doi: 10.1890/02-5122.

29. Meier, E. The Wood Database. Available online: http://www.wood-database.com (accessed 2017 April 25).

30. Mackensen, J.; Bauhus, J. Density loss and respiration rates in coarse woody debris of Pinus radiata, Eucalyptus regnans and Eucalyptus maculata. Soil Biol Biochem 2003, 35, 177-186, doi: 10.1016/S00380717(02)00255-9.

31. R Core Team. R: A language and environment for statistical computing. R Foundation for Statistical Computing, Vienna, Austria. Available online: http://www.R-project.org/. (accessed 2017 Apr 25).

32. Cornelisen, J.H.C.; Sass-Klaassen, U.; Poorter, L.; van Geffen, K.; van Logtestijn, R.S.P.; van Hal, J.; Goudzwaard, L.; Sterck, F.J.; Klaassen R.K.W.M.; Freschet, G.T.; et al. Controls on Coarse Wood Decay in Temperate Tree Species: Birth of the LOGLIFE Experiment. AMBIO 2012, 41 (Supplement 3), 231-245; DOI:10.1007/s13280-012-0304-3.

33. Harmon, M.E.; Franklin, J.F.; Swanson, F.J.; Sollins, P.; Gregory, S.V.; Lattin, J.D.; Anderson, N.H.; Cline, S.P.; Aumen, N.G.; Sedell, J.R. et al. Ecology of Coarse Woody Debris in Temperate Ecosystem. Adv Ecol Res 1986, 15, 133-302.

34. Næsset, E. Decomposition rate constants of Picea abies logs in southeastern Norway. Can J For Res 1999a, 29, 372-381, doi: 10.1139/x99-005. 